\title{
From the Foundation Stone to the Cathedral: Architecture of the Votive Church of Szeged
}

\author{
Eszter Baldavári ${ }^{1}$ \\ ${ }^{1}$ Hungarian Museum of Architecture and Monument Protection \\ Documentation Center, Budapest, Hungary \\ eszter.baldavari@gmail.com, baldavari.eszter@mma-mem.hu
}

\begin{abstract}
After the flood has demolished the largest part of Szeged the citizens decided to build a Votive church dedicated to Virgin Mary as a symbol of Hungarian national identit. After the opening design tender finally Ernö Foerk was assigned as architect to design the new church. During the years numerous events stucked the construction like from the question of the designer person, the breaking out of the World War I. till the finding of a medieval tower inside the walls of the former church. We can have a deeper glimpse into the details of the story of the architecture due to Foerk's diary is held in the Hungarian Museum of Architecture.
\end{abstract}

Keywords: architecture, Votive church, Cathedral, Dömötör tower, Ernö Foerk, Szeged, Hungary,

\section{INTRODUCTION - THE HISTORY OF THE RESEARCH}

About the Cathedral of Szeged, the most papers were written by the historian István Zombori whose essays are supplemented by the paper of József Varga. The art historian András Hadik dealt with Ernő Foerk's architecture in depth who prepared the Scientific Documentation for Monument Protection in 2013 as well. [1]

The author of this paper researched the Votive Church of Szeged between 2013 and 2015 during the reconstruction of the building as the curator of the permanent exhibition in the undercroft of the Cathedral. [2]

We have recently gained access to plenty of new information from the typewritten copy of Ernö Foerk's manuscript diary kept in the Hungarian Museum of Architecture which serves as the core of this paper. [3]

\section{THE OPEN ARCHITECTURE TENDER OF THE VOTIVE CHURCH}

The open design tender of the Votive church of Szeged was announced in 1903. [4] A specific style were not determined but it was requested that the building should be historicist, and only Hungarian materials and industrial products should be used. [5]

A first prize was not awarded in the competition because there was no recommendable one among the tenders submitted. The second prize was awarded to Sándor Aigner's and Károly Rainer's plan with the code-word "Pax", who designed only four side-altars in place of six. 
The third prize was awarded to Ernő Foerk’s [6] and Gyula Sándy’s plans called „Dicsértessék”. [7] All plans were exhibited in the Museum of Szeged for two weeks then between 11 and 25 August 1904 it could be seen in the Museum of Applied Arts in Budapest put on exhibition by the Association of Hungarian Engineers and Builders.

The statement of the general assembly of Szeged permitted the demolition of the former Saint Demetrius church with the reservation to save the monumental details. The next year at the general assembly (13 November 1908) the mayor György Lázár suggested assigning the design tender of the church and its interior directly to he popular architect Frigyes Schulek. Hence the Committee for the Construction of the Votive Church of Szeged got in contact with Frigyes Schulek who, in line with the official statement, started designing the building on 25 November 1908.

According to Foerk's diary entry from 3 December 1908 kept in the Hungarian Museum of Architecture Frigyes Schulek should have not assumed this role as he was a jury member of the tender under the terms of the new policy of architecture tenders. [8] The design contract was signed on 23 May 1909 with Frigyes Schulek who showed the first sketches to the Committee on 6 December 1909. The Committee accepted the plans with the reservation of expanding the side-aisles and supplementing them with side-chapels. Afterwards Schulek marked the accurate site of construction. However, a year turned out to be too short time for the design process. Also, as the deadline was approaching, the budget rose to almost twice as much as the previously permitted amount.

As a result, a new contract was drawn up on 3 December 1911 with the amount mentioned above, and the restriction that if Schulek were to become unable to work, the obligation and responsibility for accomplishing the assignment would be inherited by his son János Schulek. Afterwards, Frigyes Schulek prepared a reduced version of the plans with a shorter and narrower nave as well as a smaller dome and towers.

The mayor of Szeged informed Schulek about the permission of the Committee and asked him to commission the building contractors to start laying the foundation of the church. However, the architect unexpectedly terminated the contract with reference to his old age. As he wrote about it seven years after the design tender, he was about to reach his eighties so undertaking the completion of this great building would have been overly bold of him. [9]

\section{ERNŐ FOERK'S DESIGN OF THE CHURCH}

After Schulek's resignation, the mayor of Szeged made an effort to assign János Schulek but he set very high financial conditions. This way, deeming these conditions impossible to accept, the Committee recommended a new person, the architect Ernö Foerk. According to his diary he regarded Schulek's plans quite 'dry' and worse than the first sketches. He assumed only these had been drawn by Schulek himself and every other detail by his son. He started to prepare new plans because he felt the need to redesign the former ones. As he said, he did not want to work in Schulek's shadow. [10]

According to the mayor György Lázár's letter mentioned in the diary Foerk was officially commissioned on 5 January 1913. [11] He showed his plans to the Committee on 18 March 1913 in which he made some modifications to certain details. The towers were pulled back by 2-3 meters, the main entrance became more ornamented by golden mosaic and marble, the Patrona Hungariae sculpture was placed above it (which was placed too high on Schulek's plans) and a great rose window was placed on the façade.

The dome became lower and less emphasized, the towers higher and more richly decorated, and a double concrete structure was applied for the cover of the nave. 
The interior of the church was decorated by mosaics and paintings and the votive purpose materialises in a marble relief. The tower tops would have been octagonal, but the Committee insisted on Schulek's version of the towers. The execution plans and the budget were prepared by April 1913 and approved by the Committee even if not every modification had been verified by then.

The last holy mass was held on 13 July 1913 at the high altar of the former Saint Demetrius church then the demolition was started in order to create room for the new church.

\section{THE CONSTRUCTION BEGINS}

The Committee first ordered the demolition of the buildings near the downtown church. Then, on 22 July, the demolition works of the sanctuary that was blocking the way commenced, and the church was transformed in a way to enable temporary use. The local Ottovay and Winkler construction company was commissioned with the construction works on 30 June 1913. The foundation was marked on 2 August, and it began to be laid on 4 August. Ernő Foerk's deputy Gyula Petrovácz was entrusted with controlling the progress on site, while Foerk himself drew up new parts of the plan week by week. This is how Foerk wrote about this period in his diary: „The votive church is progressing well. The committee has accepted my redrawn plans to serve as a basis for the construction, so now I have the opportunity to create something good and beautiful. And we have started indeed, and now we are already above ground level. Next year, I hope, we'll reach straight. The local press colours everything in their own taste, eager to impress those hungry for a sensation. It's not that I would mind; I know what I want and what I am able to accomplish. At the moment, off-prints of the plan are already being made for the journal Épitö Ipar (i.e. 'Construction Industry'), so that I could finally give an account of my work." [12]

At the same time, he does not fail to mention Schulek in his diary: ,, In the evening, Schulek asked me about Szeged. He was lied to." [13] ,, The newspapers in Szeged mention him, and there he seems to be saying completely different things than in person. Apparently, his son John incites him." [14]

In 1914, Foerk was faced with a surprise, namely that the Committee used Schulek's plans as a basis for the creating the building's mass. ,, The town council has decided that this construction has to strictly proceed by Schulek's plans - what idiots! It is only now that they realise? When we're already above ground level and the stonemasons have been commissioned?" [15]

The Committee meeting's minutes give us an account of how Foerk, in his 'plea', presented his versions of the plans again, resulting from the fact that the Committee did not approve of the towers' simple design. He gave a richer design to these as, owing to his observations in Italy, he understood that the greyer air of Hungary demanded the towers to be more ornate in order to achieve a stronger impression. Besides, he did not think Schulek's simple reinforced concrete structure would suffice, since the church was to be heated during winter. That is why he chose a double concrete ceiling. Ten days later the Committee approved Foerk's plans again, and he presented his studies for the tower as well, so on 1 April the construction of the walls could commence. [16] Work progressed at a great speed, and on 21 June 1914 the foundation stone was laid. [17] However, on 27 July 1914 work was forced to cease due to the outbreak of World War I. The walls of the naves and sanctuaries were completed until the height of the dwarf colonnade, the towers until the second floor; still, on the façade, only the foundations were finished. "The votive church stands there as if abandoned in panic; arches, tracery, stone placements left unfinished, pieces of marble covered by rubbish. " [18] 


\section{THE CONSTRUCTION RESTARTS}

The thought of restarting the construction was proposed in 1921 when the Committee - founded in 1882 - was refounded and decided to assign Ernő Foerk to plan the process for continuing construction.

In an unexpected turn of events, the Bishop of Csanád was expelled from Timişoara, the center of the Diocese of Csanád, so he brought his seat over to Szeged in 1923.

Construction could recommence in 1923 under the direction of Ernő Foerk, Gyula Petrovácz and István Ottovay who had previously returned from the war. [19]

The carved inscription on the stone ribbon of the towers, taken from the second national anthem of Hungary titled 'Appeal', mark the exact point where the construction process had stalled earlier: "It cannot be that all in vain so many hearts have bled 1914-1918. [20]

The Tree Topping Ceremony was held on 16 September 1923, the nave and the walls of the apse were ready by October and the roof has been started as well. The cross of the crossing dome was placed on 30 August 1924. The Holy Cross altar of the transept was completed on 25 December 1924 so the first mass could be held at Christmas. The last mass was held in the former Saint Demetrius church [21] at Christmas Eve and on the same day the first mass was held in the new church by the Bishop Glattfelder. According to a citizen: "There was a moment when the two churches were of equal height. The new one was built until a certain height and the former one was demolished until a certain depth. The new was being raised while the old was being torn down and then parted from each other forever. However, it was a great moment when the two buildings lived together for a while then the former one gave over its function to the new one in 1925." [22]

\section{THE DÖMÖTÖR TOWER IS REVEALED}

During the construction of the Votive church the demolition of the baroque style Saint Demetrius church was in progress in 1925. Before the start of the demolition, the director of the town's museum, Ferenc Móra initiated that Károly Cs. Sebestyén could serve as supervisor of the work. [23]

The nave was demolished by dynamite, and the tower was to be torn down in a similar way but finally it was pulled down by mattock on Cs. Sebestyén's requests because the building was surrounded by houses.

During the work the archaeologist Cs. Sebestyén noticed an octagonal shape of walls inside the tower of the former church [24] so he informed the Hungarian National Committee of Monuments. On observing the walls, the experts confirmed that the find was truly astonishing. [25] They appealed for a protected status for the monument, then the Committee of Monuments assigned Ernö Foerk and Károly Cs. Sebestyén to design the reconstruction plans of the medieval tower. The demolished upper story and the roof were finally reconstructed and a door has been put into shape in the western wall. The ground floor has become a baptistery in 1930 decorated with frescoes painted by Vilmos Aba Novák [26], the baptismal font made of limestone and red brass prepared by Károly Weichinger.

Later the Minister for Culture, Count Kuno von Klebelsberg shared his interesting idea with the Bishop Glattfelder. As Saint Emeric of Hungary impersonated the ideal young man both morally and in his way of life, he would have wanted to prepare a dovecote on the highest floor of the Dömötör tower called 'The Doves of Saint Emeric'. As he described it, due to the numerous small windows the Dömötör tower would be the perfect place for a dovecote with various kinds of doves, at the same time avoiding directly following Venice's example. [27] 


\section{TOWARDS COMPLETION}

On 26 November 1925, the tower facing the river Tisza received its cross on the top; on 27 March 1926, the other tower as well. At Easter in 1927, Ernő Foerk began to draw up the plans for interior design. A significant amount of masonry work was required; these were entrusted to Gyula Král's company in Budapest and Béla Seenger's company; the altar was to be constructed by Sándor Auer in Szeged, while the pulpit was to be created by the company János Fischer \& Sons. The altar of the Holy Cross was mainly made of plaster, and its artificial marbling was done by Alajos Schóber, as well as that of the inside of the church walls. The metal parts of the altar were created by János Stadt.

Three out of the twelve altars of the church were created according to Ernö Foerk's plans, namely the high altar, St Gellért's altar and the altar of the Holy Cross. The St Ladislaus, the St Stephen as well as the St Demetrius altars were built according to the plans of Béla Ohmann, between 1937 and 1939. As their style follows the Roman school, they distinctly set themselves apart from all other sculptures; still, they enrich them with their considerable artistic value. [28]

Ernö Foerk drew up the plans for the ciborium, the works of which were completed in 1930. [29] It is worth noting that the bishop donated 70,000 Hungarian pengős, a full year's personal income for the completion of the altar.

We might say that the highest quality sculpture in the Votive Church of Szeged is the plaster statue by János Fadrusz, created in 1891 as an examination work on completing his studies in Vienna. [30] Legend has it that he had to tie himself to the cross and have himself photographed, so that he could use the photographs to complete the statue. He donated a plaster copy to the Szeged Fine Arts Association for the new church [31], but this received its rightful place only in 1979.

The masonry works on the façade were designed by the sculptor István Tóth; the north side entrance, 'the Gate of War' was carved by Károly Danó, according to the plans of Ernő Foerk, while the white marble relief depicting the story of the flood in Szeged was made by the sculptor János Taiszer.

The mosaic image in the sanctuary was designed by the renowned Székely artist Ferenc Márton [32] and made by Imre Zsellér's company. This is a monumental, 89.57 square-metre glass mosaic in the Byzantine style, depicting the Holy Trinity. During its design it might have been by similar works of art in Italy, since the artist, on his journey to Rome in 1924, studied the Old Christian mosaic depictions in Santa Maria Maggiore and Santa Maria in Trastevere. [33] When the mock-up, made by Ferenc Márton and stored in the Hungarian Museum of Architecture, was cleaned, the original design was revealed under the new parts; the pediment above, the two upholstery-like elements under the two main figures, and the two kneeling figures with halo on the sides, holding the hem of the others' mantles.

The Virgin Mary's mosaic image in the sanctuary was designed by Károly Reischl, and created by Imre Zsellér. The figural part of the interior painting was created by the painter Sándor Muhits, according to Foerk's plans; while the ornamental painting was done by Ottó Beszédes and his son László. [34] The interior space is enriched by the Neo-Roman architectonic elements, the Byzantine-style mosaics and figural paintings, as well as László Patay's expressive paintings. [35]

The goldsmith's works were partly done by Nándor Heksch and Lujza Boga master goldsmiths [36], e.g. the bronze gate of the main entrance, the chandeliers and the candelabra. From these, the two eleven-light candelabra can still be seen in the church in the original form. Their designs are stored in the Hungarian Museum of Architecture, as well as that of the glass window by Miksa Róth of the sanctuary depicting four saints (St Joseph, St Peter, St Paul and St John the Baptist). 
The glass window depicting St John of Nepomuk in the wall of the sanctuary was created by Imre Zsellér in the late 1920s, as well as the three-part Mary window with the row of windows on top in the left apse of the transept containing St Gellért's altar, and the St Mary window in the side apse of the transept's left part.

The rose window on the organ's choir on the main façade depicts Szeged's coat-of-arms, surrounded by those of Hungary, the countries of the Hungarian Crown and the kings of Hungary.

The swell box was created according to Ernő Foerk's plans by the Angster factory in Pécs. [37] During World War II, the whole organ was dismantled and stored in the undercroft where, unfortunately, it was rendered useless by storing. Europe's second largest organ [38] received a whole set of new manuals in 2002, which was created by the Organ Building Factory in Pécs, according to the plans of Johann Peter Trummel.

\section{THE INAUGURATION CEREMONY}

Even if, due to the economic crisis brought on by the Great Depression, the decoration of the interior was not finished completely, and the paintings and the mosaics of the dome, the plinth of the side-altars, the organ of the crypt, the benches, the confessionals were still incomplete, the church was ready to perform its sacred function.

The 900th anniversary of the Diocese of Csanád and the 50th anniversary of the pledge to construct the building were approaching so the consecration ceremony was scheduled for October 1930. The Bishop Gyula Glattfelder consecrated the Votive church and Cathedral of Our Lady on 24 October 1930 at $7 \mathrm{am}$ in Szeged. The first mass was held at 10am that day and the liturgy was led by the Papal Legate Angelo Rotta. Afterwards, by his worship, the new mayor of Szeged Szilveszter Somogyi offered the city to the Sacred Heart of Jesus.

On the same day the relic of Saint Gerard of Csanád was brought from Murano by procession, which was donated to the church of Szeged by the Patriarch of Venice - and was placed in the altar of the church. [39]

In addition, the seat of the Diocese, the Seminary of Szeged and some university buildings were built around Cathedral Square, all designed by Béla Rerrich. These were consecrated by the Bishop Glattfelder as well.

On 25 October, a piece of music titled 'The Szeged Mass' was performed, composed by Ernő Dohnányi on the occasion of the consecration. [40] Then the National Pantheon was formally opened and the capstone for the Royal Hungarian Franz Joseph University was placed.

\section{THE MYSTERIOUS SOUNDING-BOARD}

There is a plan of the tribune of the Votive church (February, 1930) lying among the documents of Foerk's heritage in the Hungarian Museum of Architecture on which there is an interesting leaf-shape sounding-board. According to the description of the plan it should be made of embossed gilded red brass. Aladár Mandola mentions that because of the inappropriate acoustic of the church a brass leaf sound-board is needed to be applied above the tribune to transmit the voice as the bishop requested. [41] Ernö Foerk also mentioned in his diary that the sounding-board had been in progress on 29 November 1930. Most fortunately, on some contemporary postcards the sound-board is visible even if it was applied for a few months. 
The sounding-leaf-board must not have been popular with the citizens because the Bishop Glattfelder informed Foerk about his dissatisfaction due to its malfunctioning as well as its unartistic appearance and asked him to remove it. [42] After the sounding-board was removed a better one was never applied.

\section{CONCLUSION}

Even numerous essays and books were published about the history of the Votive Church of Szeged, his diary, was found recently during the relocation of the Hungarian Museum of Architecture and Monument Protection Documentation Center, shed light on a plenty of circumstances in connection with the building itself. In the memoir we can get to know about Ernő Foerk's relationship with the well-known architect, Frigyes Schulek, and with his designer partner, Gyula Petrovácz. Moreover, it can be known when and how many times he visited to Szeged to inspect the construction and about what artistic ideas he debated with the Bishop Gyula Glattfelder. Due to the lines of this diary some parts of the history of the Catherdal can be clear such as the exact dates of the process and inauguration and how much Ernő Foerk was satisfied with the appreciation for the most important building in his career.

\section{REFERENCES}

[1] Hadik, A.,Fehérvári, Z.,Szeged, Fogadalmi templom, Scientific Documentation for Monument Protection Budapest, 2013. [2] The art objects of the permanent exhibition belong to the The Episcopal Museum and Treasury of Szeged-Csanád. The art historians and restorers of the Museum of Applied Arts and the colleagues of the Hungarian Castle Project Ltd took part in the organisation of this exhibiton. Hereby I would like to thank them for their work.

[3] This presentation was also held in Szeged on 22 November 2018 at the conference commemorating Ernő Foerk and Gyula Glattfelder at the Ferenc Gál College. This paper can be read in Hungarian in the publication of the Department. [4] The jury of the tender consisted of György Lázár, the mayor of Szeged, Endre Gaál, Sándor Ivánkovits, Géza Jászay, Pál Kótay, Ferenc Pálffy, Frigyes Stelczel, Mihály Tóth and Ferenc Varga, Frigyes Schulek and Győző Czigler, teachers of the Technical University of Budapest, Kamill Fittler the director of the Academy of Arts and Crafts.

[5] A szegedi fogadalmi templom, Magyar Épitőmüvészet 1930. XXX. 7-8.

[6] Foerk signed in his plans as „Förk”. According to his diary (1905) he changed his name Förk to Foerk because the name of his family has mistyped many times.

[7] Antal Hofhauser's I.N.R.I. code-word plans were recommended for purchasing and László Gyalus's O.A.M.D.G., Lajos Ybl's Patrona Hungariae and the code-words: Deo, Czentrális, Dóm, Szent Erzsébet and 1879. Finally the city of Szeged has purchased only Hofhauser's and Gyalus'. Antal Robelly prepared the technical revision of the plans of the tender.

[8] "Incredible news: the Committee does not want to give the commission to Aigner but the former jury member, Frigyes Schulek. Exactly these days the new policy of design tenders has been published. According to the Bulletin a former jury member is not allowed to have a commission neither directly nor indirectly."

[9] VARGA, J.,Adatok a szegedi Fogadalmi templom építéstörténetéhez, Móra Ferenc Múzeum Évkönyve, 1972/73-1.,

Szeged, 1974, pp.9.

[10] 4 February 1913, Foerk diary, HMA

[11] pp.56., Foerk diary, HMA

[12] November 1913, Foerk diary, HMApp.57.

[13] 19 February 1914,Foerk diary, HMApp.60.

[14] 5 March 1914, Foerk diary, HMApp.60.

[15] 8 March 1914, Foerk diary, HMApp.60.

[16] The official reports of the Committee for the Construction of the Votive Church of Szeged, HMA 
[17] "I inaugurated the celebration, we took the print of the foundation into the foundation stone",Foerk diary, HMApp.62.

[18] 19 May 1915, Foerk diary, HMApp.64.

[19] 17 August 1923, "Board meeting accepted the sculptures and arching planned for this year, the dome and the crypt for next year", Foerk diary, HMApp.83.

[20] A szegedi dóm. Különlenyomat a „Csanád Egyházmegye Jubileumi Évkönyve 1980” c. müből. (Off-print of the book of Cathedral of Szeged) Szeged, 1980

[21] 25 December 1924, "The transept of the church in Szeged has assigned to worship. The consecration was at Christmas but I did not take part in it not to be far from my family.", Foerk diary, HMA,pp.86.

[22] Mandola, A., A szegedi Fogadalmi templom. Szeged, 1930, pp.17.

[23] 13 December 1924, Foerk diary, HMA,pp.86.

[24] Cs. Sebestyén, K.,A szegedi Szent Demeter templom, Ásatások a szegedi Templom téren. Szeged, 1931, pp.205-212.

[25] The Hungarian National Committee of Monuments entrusted Kálmán Lux and Vilmos Schneller with the revision on 28 March 1925, Hungarian Museum of Architecture and Monument Protection Documentation Center - HPDC

(later MPDC), Tudományos irattár, MOB iratok 86/1925.

[26] He was awarded a golden medal at the exhibition of ecclesiastical arts in Padova in 1932.

[27] Kuno Klebelsberg and Gyula Glattfelder correspondence, 1931, Szeged, Szeged-Csanádi Püspöki Levéltár

[28] Нарік, A.,Szeged, Fogadalmi templom és Demeter-torony, Tájak, korok, múzeumok kiskönyvtára, Budapest, 2001 , pp.13.

[29] 11 December 1924, "Everything is all right, we will meet the deadline. We are about to construct the towers.

"Foerk diary, HMA, pp.86.

[30] He is awarded the Grand Prix of the Association of Fine Arts at the Winter Salon of the Art Gallery in 1892.

[31] The No. 712/1925 document of the Episcopal authority of Csanád about the purchase of János Fadrusz's Crucifix sculpture, Correspondences of Szeged, Ernő Foerk's heritage, HMA

[32] He received a degree in 1907 at the Hungarian University of Fine Arts as an art teacher. His masters were Bertalan Székely and Pál Szinyei Merse.

[33] Zoмвori, I., A szegedi dóm „nemzeti” festője: Márton Ferenc,A Móra Ferenc Múzeum Évkönyve: Studia Historica 12., Szeged, 2009, pp.228.

[34] SzöNYI, O. dr., A szegedi Fogadalmi templom, Magyar Iparmüvészet 1932. 1-2., pp. 27.

[35] Zoмвori, I., A szegedi dóm ornamentális díszítőfestése, A szegedi Dóm ornamentális díszitőfestése, 1930, pp.123.

[36] Bartháné Boga, I., A szegedi Szőriné Boga Lujza ötvös-iparmüvész életmüve. Szeged, 2013. pp.23.

[37] Коми́roмI, S., Angster és fiai orgona -és harmóniumgyára (Pécs) és a család története, Nemzeti és etnikai kisebbségek története. 2003, pp.525-527.

[38] Zoмвori, I., A Fogadalmi templomtól a püspöki székesegyházig, Móra Ferenc Múzeum Évkönyve: Studia Historica 8., Szeged, 2005, pp.407.

[39] Felszentelési ünnepség, Délmagyarország 1930. október 22., Szeged-Csanádi Püspöki Levéltár, Szeged

[40] Ernő Dohnányi composed his fifty-minute-long musical composition consisting of ten movements titled Missa In Dedicatione Ecclesiae.

[41] Mandola, 1930, pp.21.

[52] 26th May 1931, Gyula Glattfelder's and Ernő Foerk's correspondence, Ernő Foerk's heritage, HMA 